\title{
Evaluation and management of pediatric hypertensive crises: hypertensive urgency and hypertensive emergencies
}

REVIEW

This article was published in the following Dove Press journal:

Open Access Emergency Medicine

5 November 2012

Number of times this article has been viewed

\author{
Nirali H Patel' \\ Sarah K Romero ${ }^{2}$ \\ David C Kaelber ${ }^{3}$ \\ 'Division of Emergency Medicine, \\ Akron Children's Hospital, Akron, \\ $\mathrm{OH}$, USA; ${ }^{2}$ Division of Emergency \\ Medicine, Rainbow Babies and \\ Children's Hospital, Cleveland, $\mathrm{OH}$, \\ USA; ${ }^{3}$ Departments of Information \\ Services, Internal Medicine, Pediatrics, \\ and Epidemiology and Biostatistics, \\ The Center for Clinical Informatics \\ Research and Education, The \\ MetroHealth System and School of \\ Medicine, Case Western Reserve \\ University, Cleveland $\mathrm{OH}$, USA
}

Correspondence: David C Kaelber 3158 Kingsley Road, Shaker Heights, $\mathrm{OH} 44 \mathrm{I} 22$, USA

Tel + I 2164090538

Email david.kaelber@case.edu

\begin{abstract}
Hypertension (HTN) in the pediatric population is estimated to have a world-wide prevalence of $2 \%-5 \%$. As with adults, pediatric patients with HTN can present with hypertensive crises include hypertensive urgency and hypertensive emergencies. However, pediatric blood pressure problems have a greater chance of being from secondary causes of HTN, as opposed to primary HTN, than in adults. Thorough evaluation of a child with a hypertensive emergency includes accurate blood pressure readings, complete and focused symptom history, and appropriate past medical, surgical, and family history. Physical exam should include height, weight, four-limb blood pressures, a general overall examination and especially detailed cardiovascular and neurological examinations, including fundoscopic examination. Initial work-up should typically include electrocardiography, chest X-ray, serum chemistries, complete blood count, and urinalysis. Initial management of hypertensive emergencies generally includes the use of intravenous or oral antihypertensive medications, as well as appropriate, typically outpatient, follow-up. Emergency department goals for hypertensive crises are to (1) safely lower blood pressure, and (2) treat/minimize acute end organ damage, while (3) identifying underlying etiology. Intravenous antihypertensive medications are the treatment modality of choice for hypertensive emergencies with the goal of reducing systolic blood pressure by $25 \%$ of the original value over an 8 -hour period.
\end{abstract}

Keywords: hypertension, hypertensive crisis, hypertensive emergency, hypertensive urgency, pediatrics, diagnosis and treatment

\section{Introduction}

Hypertensive emergencies in children are rare and traditionally have been due to secondary underlying disease. ${ }^{1}$ Due to an increase in the incidence of metabolic syndrome, the incidence of primary hypertension (HTN) has been increasing over recent years. In a 2004 study of 5102 school age children in Texas, an overall prevalence of HTN of $4.5 \%$ was reported with the strongest determinant of HTN being body mass index (BMI) $\geq 95$ th percentile. ${ }^{2}$ The strong association of HTN with obesity and the marked increase in the prevalence of childhood obesity are significant health issues. The association of obesity with insulin resistance and HTN, otherwise known as metabolic syndrome, predisposes children to the development of cardiovascular disease. ${ }^{3}$ These comorbidities have resulted in an increasing shift to primary HTN, as the main cause of HTN in the pediatric age range. ${ }^{2}$

The definition of HTN in the pediatric population has evolved with the development of evidence-based normative data based on age, sex, and height percentile. ${ }^{1}$ Pediatric HTN is defined as systolic blood pressure (SBP) and/or diastolic blood pressure (DBP) $\geq 95$ th percentile for sex, age, and height percentile on $\geq 3$ separate occasions. Stage 1 HTN 
is defined as SBP and/or DBP measurements that range from the 95th percentile to $5 \mathrm{mmHg}$ above the 99th percentile. Stage 2 HTN is defined as SBP and/or DBP measurements that are $>5 \mathrm{mmHg}$ above the 99th percentile. Prehypertension is defined as SBP and/or DBP measurements that range from the 90th percentile to less than the 95 th percentile. ${ }^{4}$ Once confirmed on repeat measurement, stage $1 \mathrm{HTN}$ is typically non-emergent and so can be evaluated over days, weeks, or even a couple of months before initiating treatment. Patients with stage 2 HTN require prompt evaluation and pharmacologic therapy. Symptomatic patients with stage 2 HTN require immediate treatment and consultation with experts in pediatric HTN. ${ }^{4}$ Research has shown that only $15 \%-25 \%$ of hypertensive BP values are recognized by pediatric providers and recognition occurs mostly in older, taller children with recognized weight problems. ${ }^{5,6}$ Table 1 demonstrates a simplified abnormal BP screening tool, based on age and sex. This simple tool was developed to identify children and adolescents who might have prehypertension or HTN and therefore need further evaluation. ${ }^{7}$

The term 'hypertensive crisis' is used to describe an acute elevation in BP that can cause rapid end-organ damage. ${ }^{8}$ A hypertensive crisis may occur de novo or in those

Table I Simple table to identify children and adolescents needing further evaluation of blood pressure

\begin{tabular}{|c|c|c|c|c|}
\hline \multirow{2}{*}{$\begin{array}{l}\text { Age } \\
\text { (years) }\end{array}$} & \multicolumn{2}{|l|}{ Males } & \multicolumn{2}{|l|}{ Females } \\
\hline & $\begin{array}{l}\text { SBP } \\
(\mathrm{mmHg})\end{array}$ & $\begin{array}{l}\text { DBP } \\
(\mathrm{mmHg})\end{array}$ & $\begin{array}{l}\text { SBP } \\
(\mathrm{mmHg})\end{array}$ & $\begin{array}{l}\text { DBP } \\
(\mathrm{mmHg})\end{array}$ \\
\hline 3 & 100 & 59 & 100 & 61 \\
\hline 4 & 102 & 62 & 101 & 64 \\
\hline 5 & 104 & 65 & 103 & 66 \\
\hline 6 & 105 & 68 & 104 & 68 \\
\hline 7 & 106 & 70 & 106 & 69 \\
\hline 8 & 107 & 7I & 108 & 71 \\
\hline 9 & 109 & 72 & 110 & 72 \\
\hline 10 & III & 73 & 112 & 73 \\
\hline II & 113 & 74 & 114 & 74 \\
\hline 12 & 115 & 74 & 116 & 75 \\
\hline 13 & 117 & 75 & 117 & 76 \\
\hline 14 & 120 & 75 & 119 & 77 \\
\hline 15 & 120 & 76 & 120 & 78 \\
\hline 16 & 120 & 78 & 120 & 78 \\
\hline 17 & 120 & 80 & 120 & 78 \\
\hline$\geq 18$ & 120 & 80 & 120 & 80 \\
\hline
\end{tabular}

Notes: These values represent the lower limits for abnormal blood pressure by age and sex. Any blood pressure readings at or higher than these values represent blood pressures in the prehypertension, stage I hypertension, or stage 2 hypertension range and therefore should be further evaluated by a physician.

Copyright @ 2009, American Academy of Pediatrics.

Adapted with permission from Kaelber DC, Pickett F. Simple table to identify children and adolescents needing further evaluation of blood pressure. Pediatrics. 2009; 123:e972-e974. ${ }^{7}$

Abbreviations: DBP, diastolic blood pressure; SBP, systolic blood pressure. with previously diagnosed HTN. ${ }^{1}$ Hypertensive crises are further separated into hypertensive urgency and hypertensive emergency. ${ }^{8}$ Hypertensive urgency is defined as elevated BP without the presence of acute target-organ damage. These patients may manifest symptoms such as headache and nausea. ${ }^{9}$ The distinction is not absolute and depends on clinical judgement. ${ }^{8}$ A hypertensive emergency is defined by elevated BP with acute target-organ injury. Most commonly, organ injury occurs in the central nervous system, kidneys, or cardiovascular system. ${ }^{10}$ Hypertensive encephalopathy may present with the insidious onset of headache, nausea, and vomiting and can progress to severe headache, confusion, visual changes, stupor, seizure, focal neurological deficits, and coma. Hypertensive encephalopathy may also result in cerebral infarction or hemorrhage, although this is more common in adults. ${ }^{9}$

\section{Blood pressure measurement}

Accurate BP measurement is critical for the evaluation of HTN and requires a few simple steps be performed. First, the BP should be measured via auscultation in the patient's right arm, with the arm at the level of the heart, ideally with the patient in seated position. This method allows direct comparison to standardized tables. ${ }^{4,7}$ Secondly, appropriate BP cuff location, and size is important, hence a variety of cuff sizes need to be readily available. The cuff should be placed on the mid-upper arm, at a point midway between the olecranon and the acromion with the width of the inflatable bladder being at least $40 \%$ of the arm's circumference., ${ }^{4,11}$ The bladder length of the cuff should cover $80 \%-100 \%$ of the circumference of the patient's arm. ${ }^{12}$ The use of the manufacturer's lines on the cuff helps facilitate the choice of cuff for each child. ${ }^{12}$ Cuffs that are too small can give falsely elevated measurements. Conversely, cuffs that are too large, can give falsely low values. Ideally, the BP should be measured after 5 minutes of rest. While this may be difficult in a busy emergency department (ED) triage room, it is important to repeat the measurement once the child is calm in the treatment room, if the triage value is outside the normal range.

Oscillometric devices are used frequently in EDs and provide a quick measurement of BP. However, these devices assess the mean arterial BP and then calculate the systolic and diastolic values. ${ }^{13}$ The algorithms used for this calculation often vary by manufacturer. ${ }^{14}$ Additionally, these devices need to be calibrated regularly to confirm accuracy. Oscillometric devices have their advantages and role in the ED; however, an elevated BP 
on one of these devices should be confirmed by manual auscultation. ${ }^{4}$

\section{Differential diagnosis}

Secondary causes of HTN are more common in pediatric patients then in adults, particularly if the BP is elevated enough to cause hypertensive urgency or emergency. The differential diagnosis of pediatric hypertensive urgencies and emergencies are a function of age. In newborn infants, common etiologies include structural lesions such as renal vascular abnormalities, congenital renal and urologic anomalies, and aortic coarctation. ${ }^{10}$ From infancy to 6 years, secondary causes of pediatric HTN, including acute and chronic renal parenchymal diseases, continue to be much more likely than primary causes of pediatrics HTN. Acute presentations of hypertensive crises include hemolytic uremic syndrome and acute glomerulonephritis. ${ }^{8}$ Coarctation of the aorta and renal artery stenosis should also be considered in this early age group. ${ }^{10,15}$ Among younger school age children, primary HTN becomes more prevalent, although still remains less common than renal parenchymal and vascular causes. ${ }^{10}$ After $10-12$ years of age, primary HTN becomes the leading cause of pediatric HTN. ${ }^{15}$ While obesityrelated HTN rarely leads to acute hypertensive urgency or emergency, chronic organ failure can occur from HTN in patients with untreated obesity. Other causes of HTN can include withdrawal from chronic antihypertensive medications such as clonidine or $\beta$-adrenergic blockers, abuse of recreational drugs such as cocaine or amphetamine, medications such as oral contraceptive pills, corticosteroids, ephedrine, or pseudoephedrine, and elevated intracranial pressure. ${ }^{15,16}$ Severe fluid overload in patients on dialysis may also lead to severe, symptomatic HTN. ${ }^{8}$ Rare endocrinologic pathology such as pheochromocytoma, hyperthyroidism and Cushing's syndrome should also be considered in the broad differential diagnosis for all age groups as well. A summary of etiologies of HTN appears in Table 2.

Table 2 Etiology of hypertensive urgency and emergency

\begin{tabular}{|c|c|c|c|}
\hline Age & Etiology & History & Physical examination \\
\hline $0-1$ year & $\begin{array}{l}\text { - Renal artery and venous thrombosis } \\
\text { - Autosomal recessive polycystic } \\
\text { kidney disease } \\
\text { - Aortic coarctation } \\
\text { - Congenital nephritic syndrome } \\
\text { - Other renal parenchymal disease } \\
\text { - Renal artery stenosis } \\
\text { - Tumor } \\
\text { - latrogenic } \\
\text { - Mydriatics } \\
\text { - Theophylline overdose } \\
\text { - Caffeine overdose }\end{array}$ & $\begin{array}{l}\text { - Umbilical artery catherization } \\
\text { - Oligohydramnios } \\
\text { - Prolonged mechanical ventilation } \\
\text { - Family history of renal disease } \\
\text { - Medications }\end{array}$ & $\begin{array}{l}\text { - Pulse quality and blood pressure } \\
\text { in four extremities } \\
\text { - Signs of congestive heart failure } \\
\text { - Abdominal mass and bruit } \\
\text { - Ambiguous genitalia }\end{array}$ \\
\hline $\mathrm{I}-12$ years & $\begin{array}{l}\text { - Renal parenchymal disease } \\
\text { - Polycystic kidney disease } \\
\text { - Renovascular disease } \\
\text { - Tumor } \\
\text { - Endocrine causes } \\
\text { - Aortic coarctation }\end{array}$ & $\begin{array}{l}\text { - Poor feeding } \\
\text { - Failure to gain weight } \\
\text { - History of urinary tract infection } \\
\text { - History of low birth weight } \\
\text { - Family history of renal disease } \\
\text { - Headache, palpitations, blurred vision } \\
\text { - Medications } \\
\text { - Accidental ingestion }\end{array}$ & $\begin{array}{l}\text { - Heart rate, body mass index, pulse quality } \\
\text { - Card blood pressure in four extremities } \\
\text { examination } \\
\text { - Abdominal mass and bruit } \\
\text { - Rash } \\
\text { - Peripheral edema } \\
\text { - Retinal examination } \\
\text { - Ambiguous genitalia }\end{array}$ \\
\hline $13-18$ years & $\begin{array}{l}\text { - Essential hypertension } \\
\text { - Metabolic syndrome } \\
\text { - Renal parenchymal disease } \\
\text { - latrogenic } \\
\text { - Anabolic steroids } \\
\text { - Substance abuse } \\
\text { - Decongestants } \\
\text { - Renovascular disease } \\
\text { - Aortic coarctation } \\
\text { - Endocrine causes }\end{array}$ & $\begin{array}{l}\text { - Excessive weight gain } \\
\text { - History of fever and/or joint pain } \\
\text { - History of urinary tract infection } \\
\text { - History of low birth weight } \\
\text { - Family history of hypertension } \\
\text { or renal disease } \\
\text { - Medications } \\
\text { - Drug overdose } \\
\text { - Headache, palpitation, blurred vision }\end{array}$ & $\begin{array}{l}\text { - Heart rate, body mass index, pulse quality } \\
\text { - Card blood pressure in four extremities } \\
\text { - Thyroid examination } \\
\text { - Abdominal mass and bruit } \\
\text { - Rash } \\
\text { - Peripheral edema } \\
\text { - Retinal examination }\end{array}$ \\
\hline
\end{tabular}

Note: Copyright (C) 2012, Springer.

Adapted with permission from Chandar J, Zilleruelo G. Hypertensive crisis in children. Pediatr Nephrol. 2012;27(5):74I-75I.' 


\section{Evaluation}

\section{History}

HTN in children is most likely to have an underlying cause, especially if severe. ${ }^{8}$ Very young children, children with stage 2 HTN, and children or adolescents with clinical signs that suggest the presence of systemic conditions associated with HTN should be evaluated more extensively. ${ }^{4}$

A thorough history and physical examination are essential for the evaluation of HTN, and should be focused on assessing end-organ damage, and on determining etiology. ${ }^{8}$ Severe HTN may be detected incidentally, particularly in those with long standing HTN that have acclimated and show few overt clinical symptoms. Presentations may include cardiac failure or neurologic manifestations (headache, vomiting, irritability, lethargy, altered sensorium, seizures, and facial palsy). ${ }^{8}$ It is important to seek signs and symptoms suggesting renal disease (proteinuria, edema, anemia), heart disease (chest pain, exertional dyspnea, palpitations), and diseases of other organ systems (endocrinologic, rheumatologic). ${ }^{4}$ In neonates, initial symptoms such as emesis and poor feeding can be nonspecific signs of HTN. ${ }^{1}$

Past medical and social history including trauma, urinary tract infections, umbilical vein catheterization, snoring, sleep problems, drug/herbals use (such as abuse of recreational drugs, oral contraceptives, and steroids) and nutritional supplement use should be investigated to tease out potential underlying etiologies. ${ }^{4}$ Establishing a prior history and treatment of HTN is important as abrupt withdrawal of some hypertensive medications may cause hypertensive crises. ${ }^{10}$

Family history of HTN or endocrinopathies can also provide useful clues to the etiology of a child's $\mathrm{HTN}^{10}$ and is often overlooked. ${ }^{17}$

\section{Physical exam}

A physical examination of someone with suspected HTN should include a full set of vital signs, including four-limb blood pressures. ${ }^{10}$ An accurate weight and height should also be obtained. Fundoscopic exam and a full neurologic exam should be done to assess for hypertensive encephalopathy. ${ }^{10}$ Fundoscopic exam may be difficult in younger children and may necessitate consultation by a pediatric ophthalmologist. The cardiovascular exam should focus on signs of ventricular hypertrophy or cardiac failure, including signs of pulmonary edema, hepatomegaly, additional heart sounds (especially S3 and S4), tachycardia, or a displaced apical impulse. The absence of femoral pulses should raise a suspicion for coarctation of the aorta. Renal artery bruits, edema, or growth failure may point to an underlying renal cause for HTN. ${ }^{10}$ System specific physical exam findings may be helpful in determining the underlying etiology (Table 3 ).

\section{Investigations}

Diagnostic testing for hypertensive urgencies and emergencies in the ED should be limited to simple investigations, as the primary goal in the ED is to acutely lower the BP. Initial investigations in the ED depend on findings from the history and physical exam. ${ }^{10}$ Laboratory studies should include urinalysis (specifically concentrating ability and presence of proteinuria), serum chemistries (including blood urea nitrogen, creatinine for baseline renal function, as well as for evidence of hypokalemic alkalosis found in HTN associated with renal vein stenosis ${ }^{1}$ ), and a compete blood count (to evaluate for evidence of microangiopathic hemolytic anemia as would be seen in hemolytic uremic syndrome and for anemia seen in chronic kidney disease). An electrocardiogram and chest X-ray should be considered to evaluate for signs of congestive heart failure or myocardial hypertrophy. ${ }^{18}$ Computed tomography of the head may be warranted in the presence of abnormal neurological findings. Further testing after stabilization may include urine for catecholamines (neuroendocrine tumors), renal ultrasound with Doppler (structural abnormalities), complement C3 (acute glomerulonephritis), antinuclear antibody (lupus), echocardiography (structural abnormalities, end-organ damage, and left-ventricular hypertrophy), renin, aldosterone, and cortisol (Conn syndrome), TSH (hyperthyroidism), urine toxicology (abuse of recreational drugs including phencyclidine, cocaine metabolites, amphetamines), and urine pregnancy in postmenarcheal females (preeclampsia). ${ }^{1,10}$

\section{Management}

The majority of mild-to-moderate pediatric HTN seen in the ED does not require immediate intervention. These cases mandate close outpatient follow-up, evaluation, and management. Educating families prior to discharge about the consequences of incomplete follow-up is critical to reducing morbidity and mortality.

Hypertensive crises, however, necessitate immediate intervention to safely and effectively lower the BP. Current recommendations advise no more than a $25 \%$ reduction of SBP in the first 8 hours, followed by a gradual return to normal BP over 26 to 48 hours. ${ }^{4,16} \mathrm{~A}$ larger reduction in pressure can worsen end-organ function, lead to worsening neurological status, and possibly cause cerebrovascular compromise; 
Table 3 Examples of physical examination findings suggestive of definable hypertension

\begin{tabular}{|c|c|c|}
\hline System & Finding* & Possible etiology \\
\hline Vital signs & $\begin{array}{l}\text { Tachycardia } \\
\text { Decreased lower extremity pulses; drop in blood } \\
\text { pressure from upper to lower extremities }\end{array}$ & $\begin{array}{l}\text { Hyperthyroidism, pheochromocytoma, } \\
\text { neuroblastoma, primary hypertension } \\
\text { Coarctation of the aorta }\end{array}$ \\
\hline Eyes & Retinal changes & $\begin{array}{l}\text { Severe hypertension, more likely to be associated } \\
\text { with secondary hypertension }\end{array}$ \\
\hline Ear, nose, and throat & Adenotonsillar hypertrophy & $\begin{array}{l}\text { Suggests association with sleep-disordered } \\
\text { breathing (sleep apnea), snoring }\end{array}$ \\
\hline \multirow[t]{3}{*}{ Height/weight } & Growth retardation & Chronic renal failure \\
\hline & Obesity (high body mass index) & Primary hypertension \\
\hline & Truncal obesity & Cushing's syndrome, insulin resistance syndrome \\
\hline \multirow[t]{4}{*}{ Head and neck } & Moon-faced & Cushing's syndrome \\
\hline & Elfin-faced & William's syndrome \\
\hline & Webbed neck & Turner syndrome \\
\hline & Thyromegaly & Hyperthyroidism \\
\hline \multirow[t]{6}{*}{ Skin } & Pallor, flushing, diaphoresis & Pheochromocytoma \\
\hline & Acne, hirsutism, striae & Cushing's syndrome, anabolic steroid use \\
\hline & Café-au-lait spots & Neurofibromatosis \\
\hline & Adenoma sebaceum & Tuberous sclerosis \\
\hline & Malar rash & Systemic lupus erythematosus \\
\hline & Acanthosis nigricans & Type 2 diabetes \\
\hline \multirow[t]{6}{*}{ Chest } & Widely spaced nipples & Turner syndrome \\
\hline & Heart murmur & Coarctation of the aorta \\
\hline & Friction rub & Systemic lupus erythematosus (pericarditis), \\
\hline & Apical heave & collagen-vascular disease, end stage \\
\hline & & Renal disease with uremia \\
\hline & & Left ventricular hypertrophy/chronic hypertension \\
\hline \multirow[t]{3}{*}{ Abdomen } & Mass & Wilms tumor, neuroblastoma, pheochromocytoma \\
\hline & Epigastric/flank bruit & Renal artery stenosis \\
\hline & Palpable kidneys & $\begin{array}{l}\text { Polycystic kidney disease, hydronephrosis, } \\
\text { multicystic dysplastic kidney, mass (see above) }\end{array}$ \\
\hline Genitalia & Ambiguous/virilization & Adrenal hyperplasia \\
\hline \multirow[t]{3}{*}{ Extremities } & Joint swelling & Systemic lupus erythematosus, collagen \\
\hline & Muscle weakness & vascular disease \\
\hline & & Hyperaldosteronism, Liddle's syndrome \\
\hline
\end{tabular}

Note: *Findings listed are examples of findings and do not represent all possible physical findings. Adapted from Flynn, JT, Evaluation and management of hypertension in childhood. Progress in Pediatric Cardiology. 200I:12(2); 177-188. Copyright 200I with permission from Elsevier. ${ }^{30}$

and should therefore be avoided. ${ }^{19}$ This is particularly true in cases of long-standing HTN where autoregulatory compensation has occurred. In these circumstances, blood flow increases as mean arterial pressure increases. The body compensates through cerebral vasoconstriction and adaptations such as arteriolar hypertrophy, shifting the autoregulatory range to a higher range than in normotensive patients..$^{9,19}$

Hypertensive emergencies are most commonly treated with intravenous (IV) medications. This allows for easier titration and control of the rate of decrease in BP. There have been a limited number of pediatric studies, and most treatment guidelines are based on experience. Many drugs used in the treatment of hypertensive emergencies are not approved by the US Food and Drug Administration for use in children and are used on an off-label basis. ${ }^{16}$ It is important to understand the unique properties and adverse effects associated with these medications. Table 4 highlights drugs commonly used to treat hypertensive emergencies in children. Key medications for hypertensive emergencies are discussed below.

\section{Sodium nitroprusside}

Sodium nitroprusside is a direct arterial and venous smooth muscle vasodilator. It is one of the more commonly used agents in pediatric hypertensive emergencies due to its ease of titration to fluctuations in BP, its short half-life, and therefore rapid onset and termination of effects. It is administered as a continuous infusion. The dosage range is $0.3-0.5 \mu \mathrm{g} / \mathrm{kg} / \mathrm{min}$ to a maximum of $8 \mu \mathrm{g} / \mathrm{kg} / \mathrm{min}$. Most patients respond to a rate of approximately $3 \mu \mathrm{g} / \mathrm{kg} / \mathrm{min} .^{10,20}$

Sodium nitroprusside is metabolized in erythrocytes to cyanide, then converted to thiocyanide in the liver and excreted by the kidneys. Extreme caution should be taken using this medication in children with hepatic or renal impairment. 
Table 4 Antihypertensive drugs for management of severe hypertension in children $1-17$ years old

\begin{tabular}{|c|c|c|c|c|}
\hline \multicolumn{5}{|l|}{ Most Useful ${ }^{\dagger}$} \\
\hline Drug & Class & Dose* & Route & Comments \\
\hline Esmolol & $\beta$-blocker & $100-500 \mathrm{mcg} / \mathrm{kg} / \mathrm{min}$ & iv infusion & $\begin{array}{l}\text { Very short-acting_constant infusion } \\
\text { preferred. May cause profound } \\
\text { bradycardia. } \\
\text { Produced modest reductions in BP } \\
\text { in a pediatric clinical trial. }\end{array}$ \\
\hline Hydralazine & Vasodilator & $0.2-0.6 \mathrm{mg} / \mathrm{kg} /$ dose & iv, im & $\begin{array}{l}\text { Should be given every } 4 \text { hours when } \\
\text { given iv bolus. } \\
\text { Recommended dose is lower } \\
\text { than FDA label. }\end{array}$ \\
\hline Labetalol & $\begin{array}{l}\alpha \text { - and } \\
\beta \text { - blocker }\end{array}$ & $\begin{array}{l}\text { bolus: } 0.2-1.0 \mathrm{mg} / \mathrm{kg} / \text { dose } \\
\text { up to } 40 \mathrm{mg} / \text { dose } \\
\text { infusion: } 0.25-3.0 \mathrm{mg} / \mathrm{kg} / \mathrm{hr}\end{array}$ & $\begin{array}{l}\text { iv bolus } \\
\text { or } \\
\text { infusion }\end{array}$ & $\begin{array}{l}\text { Asthma and overt heart failure are } \\
\text { relative contra- indications. }\end{array}$ \\
\hline Nicardipine & $\begin{array}{l}\text { Calcium channel } \\
\text { blocker }\end{array}$ & $\mathrm{I}-3 \mathrm{mcg} / \mathrm{kg} / \mathrm{min}$ & iv infusion & May cause reflex tachycardia. \\
\hline $\begin{array}{l}\text { Sodium } \\
\text { nitroprusside }\end{array}$ & Vasodilator & $0.53-10 \mathrm{mcg} / \mathrm{kg} / \mathrm{min}$ & iv infusion & $\begin{array}{l}\text { Monitor cyanide levels with prolonged } \\
(>72 \mathrm{hr} \text { ) use or in renal failure; or } \\
\text { coadminister with sodium thiosulfate. }\end{array}$ \\
\hline \multicolumn{5}{|c|}{ Occasionally useful ${ }^{\ddagger}$} \\
\hline Drug & Class & Dose* & Route & Comments \\
\hline Clonidine & $\begin{array}{l}\text { Central } \\
\alpha \text {-agonist }\end{array}$ & $\begin{array}{l}0.05-0.1 \mathrm{mg} / \text { dose may } \\
\text { be repeated up to } 0.8 \mathrm{mg} \\
\text { total dose }\end{array}$ & po & $\begin{array}{l}\text { Side effects include dry mouth and } \\
\text { sedation. }\end{array}$ \\
\hline Enalaprilat & ACE inhibitor & $\begin{array}{l}0.05-0.1 \mathrm{mg} / \mathrm{kg} / \mathrm{dose} \text { up to } \\
1.25 \mathrm{mg} / \text { dose }\end{array}$ & iv bolus & $\begin{array}{l}\text { May cause prolonged hypotension } \\
\text { and acute renal failure, especially } \\
\text { in neonates. }\end{array}$ \\
\hline Fenoldopam & $\begin{array}{l}\text { Dopamine } \\
\text { receptor agonist }\end{array}$ & $0.2-0.8 \mathrm{mcg} / \mathrm{kg} / \mathrm{min}$ & iv infusion & $\begin{array}{l}\text { Produced modest reductions in BP } \\
\text { in a pediatric clinical trial in patients } \\
\text { up to } 12 \text { years. }\end{array}$ \\
\hline Isradipine & $\begin{array}{l}\text { Calcium channel } \\
\text { blocker }\end{array}$ & $0.05-0.1 \mathrm{mg} / \mathrm{kg} / \mathrm{dose}$ & po & $\begin{array}{l}\text { Stable suspension can be } \\
\text { compounded. }\end{array}$ \\
\hline Minoxidil & Vasodilator & $0.1-0.2 \mathrm{mg} / \mathrm{kg} /$ dose & po & $\begin{array}{l}\text { Most potent oral vasodilator; long- } \\
\text { acting. }\end{array}$ \\
\hline
\end{tabular}

Notes: Hydralizine is US FDA approved for the treatment of hypertensive emergencies and hypertensive urgencies in the pediatric population. Sodium nitroprusside is US FDA approved for the treatment of hypertensive emergencies in the pediatric population. Fenoldopam and Minoxidil are US FDA approved for the treatment of hypertensive urgencies in the pediatric population. Pediatric hypertensive emergencies and/or hypertensive urgencies are not US FDA approved indications for the use of esmolol, labetalol, nicardipine, clonidine, enalaprilat, or isradipine. Reprinted from U.S. Department of Health and Human Services, Public Health Service, National Institutes of Health, National Heart, Lung, and Blood Institute. NIH Publication No. 05-5267. 2005. ${ }^{4}$

tUseful for hypertensive emergencies and some hypertensive urgencies. Useful for hypertensive urgencies and some hypertensive emergencies. *All dosing recommendations are based upon expert opinion or case series data except as otherwise noted.

Abbreviations: ACE, angiotensin-converting enzyme; im, intramuscular; iv, intravenous; po, oral.

Special precautions, such as monitoring for cyanide toxicity should be used in cases where sodium nitroprusside is used for longer than 24 to 48 hours or if used in doses higher than $3 \mu \mathrm{g} / \mathrm{kg} / \mathrm{min} .{ }^{10,20}$ For prevention of cyanide toxicity, sodium thiosulfate, sodium nitrite, and amyl nitrite may be used. Amyl nitrite is currently used off-label for pediatric patients and not routinely recommended. More commonly, sodium thiosulfate is used. It is mixed with the sodium nitroprusside drip at a ratio of $10 \mathrm{mg}$ sodium thiosulfate to $1 \mathrm{mg}$ of sodium nitroprusside. Sodium nitrite may also be used, but caution is needed as it may lead to methhemoglobinemia. ${ }^{19}$

\section{Hydralazine}

Hydralazine is a very potent arterial vasodilator that is used to reduce SBP. Its onset of action varies from 5 to 30 minutes with duration of action lasting 4 to 12 hours. Hydralazine is only available in bolus form, making it less predictable and more difficult to titrate. As a result, it has been largely replaced by more easily controlled medications. However, it has been used to control severe HTN in certain situations, particularly in neonates and pregnant teenagers. Another advantage of hydralazine is that it can be administered intramuscularly. This is especially useful when there is an immediate need to lower 
the BP and the patient does not have IV access. ${ }^{16}$ Hydralazine may cause a lupus-like syndrome in slow acetylators, ${ }^{4}$ reflex tachycardia, and salt and water retention. ${ }^{9}$ Headache is also a common side effect, complicating symptomatology.

\section{Esmolol}

Esmolol is a rapid onset, ultrashort-acting, cardioselective $\beta_{1}$-adrenergic-blocking agent. Its rapid metabolism by an intracytoplasmic red blood cell esterase is independent of both renal and hepatic metabolism, making it well suited for critically ill children with multiorgan failure. ${ }^{16}$ It is particularly useful in the management of hypertensive crisis associated with repair of congenital heart disease. Side effects are similar to those of any other beta-blocking agents including bronchospasm, bradycardia, and congestive heart failure. ${ }^{10}$

\section{Fenoldopam}

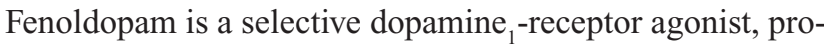
ducing vasodilatation of the renal, coronary, cerebral, and splanchnic vasculature resulting in arterial dilatation and a lowering of the mean arterial pressure. ${ }^{21,22}$ Peak effects are seen within 5-15 minutes of infusion of the drug. Steady state is reached within 30 to 60 minutes of administration. ${ }^{21}$ Clinical effects dissipate quickly once the infusion is stopped. The dose should be started at $0.2 \mu \mathrm{g} / \mathrm{kg} / \mathrm{min}$ and may be increased every $20-30$ minutes to $0.3-0.5 \mu \mathrm{g} / \mathrm{kg} / \mathrm{min}$. The maximum dose is $0.8 \mu \mathrm{g} / \mathrm{kg} / \mathrm{min}$; doses higher than this have been shown to worsen tachycardia without any additional BP benefits. ${ }^{21,22}$ Side effects include reflex tachycardia, increased intracranial pressure, and increased intraocular pressure. ${ }^{10}$

\section{Labetalol}

Labetalol is an $\alpha$ - and $\beta$-sympathetic blocker that decreases peripheral vascular resistance with little or no effect on cardiac output. ${ }^{16}$ It can be given as a bolus or continuous IV infusion. Effects appear within 2-5 minutes of administration; however, its long plasma half-life (3-5 hours) makes it more difficult to titrate. Labetalol is contraindicated in patients with asthma or chronic lung disease as it may precipitate bronchospasm, as well as in patients with hyperkalemia or congestive heart failure due to its negative inotropic and dromotropic effects. It may also mask symptoms of hypoglycemia and should be used cautiously in children with diabetes. ${ }^{10}$

\section{Nicardipine}

Nicardipine is an IV dihydropyridine calcium channel blocker that reduces peripheral vascular resistance with limited inotropic, chronotropic, and dromotropic cardiac effects. ${ }^{10}$ It can be used in patients with bronchospasm and renal and hepatic failure. Onset of action begins within 15 minutes, with a half-life of 10-15 minutes. Dosing may start at 0.5 to $1 \mu \mathrm{g} / \mathrm{kg} / \mathrm{min}$ to a maximum of $3 \mu \mathrm{g} / \mathrm{kg} / \mathrm{min}$. Side effects include increased intracranial pressure due to cerebral vasodilatation and should be used with caution in patients with space occupying lesions. Other side effects include thrombophlebitis when given through a peripheral line, headache, nausea, tachycardia and hypotension. ${ }^{10}$ Of note, nicardipine needs to be diluted in a large amount of volume, which may limit its use in those with volume overload.

\section{Nifedipine}

Nifedipine is a short-acting calcium channel blocker. There is much controversy in using nifedipine to treat HTN in the pediatric population. Much of the controversy is based on adult literature, where sudden hypotension has led to ischemic complications such as strokes and myocardial ischemia. ${ }^{10,23,24}$ Data in the pediatric literature is limited. Blaszak et $\mathrm{al}^{25}$ conducted a chart review of 117 patients who received a total of 520 nifedipine doses. An initial dose of nifedipine less than $0.25 \mathrm{mg} / \mathrm{kg}$ was safe and effective, and no clinically significant side effects were noted. Egger et $\mathrm{al}^{26}$ performed a review of 166 patients who received nifedipine for HTN (1746 doses). Several cases of profound and unpredictable changes in BP were noted. A few patients had clinically significant adverse events. These included change in neurologic status in six cases, profound hypotension in two patients, and oxygen desaturations in 16 cases. In many of these cases, patients had severe underlying disease and confounding factors that may have accounted for the events. However, due to the serious nature of the outcomes (stroke, seizures, altered level of consciousness, or severe symptomatic hypotension), clinicians should take great caution in using nifedipine for hypertensive emergencies in children.

\section{Conclusion}

Hypertensive crises are rare in children, but must be recognized and treated promptly. Goals of ED evaluation and management are to (1) safely lower BP, and (2) treat/ minimize acute end-organ damage while (3) identifying underlying etiology. IV antihypertensives are the treatment modality of choice for hypertensive emergencies with the goal of reducing SBP 25\% of the original value over an 8-hour period. 


\section{Acknowledgments}

We thank Michael L Forbes, MD, Deepa Chand, MD, Maureen Vaughan, MD, Sandya Sasi, MD and Deanna Dahl-Grove, MD for their critical review of the article.

\section{Disclosure}

The authors report no conflicts of interest in this work.

\section{References}

1. Chandar J, Zilleruelo G. Hypertensive crisis in children. Pediatr Nephrol. 2012;27(5):741-751.

2. Sorof JM, Lai D, Turner J, et al. Overweight, ethnicity, and the prevalence of hypertension in school-aged children. Pediatrics. 2004; 113:475-482.

3. Yang WC, Wu HP. Clinical analysis of hypertension in children admitted to the emergency department. Pediatr Neonatol. 2010;51(1):44-51.

4. National Heart, Lung, and Blood Institute. The fourth report on the diagnosis, evaluation, and treatment of high blood pressure in children and adolescents. U.S. Department of Health and Human Services, Public Health Service, National Institutes of Health, National Heart, Lung, and Blood Institute. NIH Publication No. 05-5267. 2005.

5. Mitchell CK, Theriot JA, Sayat JG, et al. A simplified table improves the recognition of paediatric hypertension. J Paediatr Child Health. 2011;47:22-26.

6. Hansen ML, Gunn PW, Kaelber DC. Underdiagnosis of hypertension in chidren and adolescents. JAMA. 2007;298(8):874-879.

7. Kaelber DC, Pickett F. Simple table to identify children and adolescents needing further evaluation of blood pressure. Pediatrics. 2009;123:e972-e974.

8. Hari P, Sinha A. Hypertensive emergencies in children. Indian J Pediatr. 2011;78(5):569-575.

9. Patel HP. Mitsnefes M. Advances in the pathogenesis and management of hypertensive crisis. Curr Opin Pediatr. 2005;17(2):210-214.

10. Constantine E, Linakis J. The assessment and management of hypertensive emergencies and urgencies in children. Pediatric Emerg Care. 2005;21(6):391-396.

11. Gomez-Marin O, Prineas RJ, Rastam L. Cuff bladder width and blood pressure measurement in children and adolescents. $J$ Hypertens. 1992;10(10):1235-1241.

12. National High Blood Pressure Education Program Working Group on Hypertension Control in Children and Adolescents. Update on the 1987 Task Force Report on High Blood Pressure in Children and Adolescents: a working group report from the National High Blood Pressure Education Program. Pediatrics. 1996;98:649-658.

13. Butani L, Morgenstern BZ. Are pitfalls of oxcillometric blood pressure measurements preventable in children? Pediatr Nephrol. 2003; $18: 313-318$
14. Kaufman MA, Pargger H, Drop LJ. Oscillometric blood pressure measurements by different devices are not interchangeable. Anesth Analg. 1996;82(2):377-381.

15. Constantine E. Hypertension. In: Ludwig S, Fleisher GR, editors. Textbook of Pediatric Emergency Medicine. 6th ed. Philadelphia, PA: Lippincott Williams \& Wilkins; 2010:315-323.

16. Flynn JT, Tullus K. Severe hypertension in children and adolescents: pathophysiology and treatment. Pediatr Nephrol. 2009;24(6): 1101-1112.

17. Benson L, Baer HJ, Greco PJ, Kaelber DC. When is family history obtained? Lack of timely documentation of family history among overweight and hypertensive paediatric patients. J Paediatr Child Health. 2010;46(10):600-605.

18. Constantine E, Merritt C. Hypertensive emergencies in children: identification and management of dangerously high blood pressure. Minerva Pediatr. 2009;61:175-184.

19. Vaughan CJ, Delanty N. Hypertensive Emergencies. Lancet. 2000; 356(9227):411-417.

20. Lexi-Comp Online. Lexi-Drugs Online. Nitroprusside. Hudson, OH: Lexicomp, Inc; 2012. http://online.lexi.com/lco/action/doc/retrieve/ docid/patch_f/7378. Accessed April 3, 2012.

21. Lexi-Comp Online. Lexi-Drugs Online. Fendolopam. Hudson, OH: Lexicomp, Inc; 2012. http://online.lexi.com/lco/action/doc/retrieve/ docid/patch_f/6898. Accessed April 3, 2012.

22. Strauser LM, Pruitt RD, Tobias JD. Initial experience with fenoldopam in children. Am J Ther. 1999;6(5):283-288.

23. Hammer GB, Verghese ST, Drover DR, et al. Pharmacokinetics and pharmacodynamics of fenoldopam mesylate for blood pressure control in pediatric patients. BMC Anesthesiology. 2008;8:6.

24. Yiu V, Orrbine E, Rosychuk RJ, et al. The safety and use of short-acting nifedipine in hospitalized hypertensive children. Pediatr Nephrol. 2004;19(6):644-650.

25. Leonard MB, Kasner SE, Feldman HI, Schulman SL. Adverse neurologic events associated with rebound hypertension after using short-acting nifedipine in childhood hypertension. Pediatr Emerg Care. 2001;17(6):435-437.

26. Blaszak RT, Savage JA, Ellis EN. The use of short-acting nifedipine in pediatric patients with hypertension. J Pediatr. 2001;139(1):34-37.

27. Egger DW, Deming DD, Hamada N, Sahney S. Evaluation of the safety of short-acting nifedipine in children with hypertension. Pediatr Nephrol. 2002;17(1):35-40.

28. Suresh S, Mahajan P, Kamat D. Emergency management of pediatric hypertension. Clin Pediatr. 2005;44:739-745.

29. Munter P, He J, Cutler JA, et al. Trends in blood pressure among children and adolescents. JAMA. 2004;291(17):2107-2113.

30. Flynn, JT, Evaluation and management of hypertension in childhood. Progress in Pediatric Cardiology. 2001;12(2):177-188.
Open Access Emergency Medicine

\section{Publish your work in this journal}

Open Access Emergency Medicine is an international, peer-reviewed, open access journal publishing original research, reports, editorials, reviews and commentaries on all aspects of emergency medicine. The manuscript management system is completely online and includes a very quick and fair peer-review system, which is all easy to use.

\section{Dovepress}

Visit http://www.dovepress.com/testimonials.php to read real quotes from published authors. 